\title{
An Empirical Study on Problems Faced By Women Employees in Information Technology Industry with Special Reference to Coimbatore City
}

\author{
Dr.A.Kumudha ${ }^{1}$, J. Jancy Rani ${ }^{2}$ \\ ${ }^{1}$ Associate Professor, ${ }^{2}$ M.Phil Research Scholar \\ Department of Business Management, PSGR Krishnammal College for Women, Coimbatore
}

\begin{abstract}
This paper outlines the various problems faced by women employees in Information Technology industry with special reference to Coimbatore city. The introduction of computer-based technology into clerical work can build on women's skills, and may have given them new opportunities to enhance human skills. But in today's world where a woman wants to support her family financially and is trying to balance her personal and professional life she is facing a lot of problems related to work, their kids and lot of personal problems. There is lot of physical, psychological, medical effects, discrimination at the work and it affects her work as well as family. For the purpose of research the sample of 120 people, who are working in Information Technology industry in Coimbatore has been considered. The primary data has been collected using the questionnaires. Descriptive type of research design \& Convenience sampling method has been used. The research work reveals that most of the respondents are facing various physical and psychological problems due to their nature of work. Suggestions have been given, which would help the women employees to overcome their problems.
\end{abstract}

Keywords: Information Technology Industry, Physical problems, Psychological problems.

\section{INTRODUCTION}

During the last quarter of this century Information Technology (IT) has transformed the way of human life as no other technology has. Now, there is no area of human life, which is not affected by information technology in one way or the other.
This industry has succeeded not only in achieving global competitiveness but also raising awareness of the benefit of Information Technology within the country thereby laying the platform for future growth. In highly skilled intensive and knowledge intensive industries like information technology industry, human resources play a vital role. This industry is highly competitive, dynamic and technical industry, whose growth and development depends upon its human resources much more strongly than other resources.

\section{PROBLEM FACED BY WOMEN EMPLOYEES IN INFORMATION TECHNOLOGY INDUSTRY}

It is an open truth that working women have to face problems just by virtue of their being women. The age old belief of male superiority over women creates several hurdles for women at their place of work. Working in Information Technology industry inevitably puts strains on women to greater extent as compared to men. Women in Information Technology industry suffer from physical discomfort, psychological problems and mental tension. The physical problems were mostly in the form of musculoskeletal disorders, digestive disorders, eye, voice and hearing problems. Inspite of this there are certain other consequences of sedentary lifestyle such as anxiety, depression, faulty eating habits, mental tension, sleep disturbance, nightmares. Late working hours, long working hours at the desk, job related pressure, deadlines and problem of balancing work at home and office are some of the 
mental tensions that resist women employees to stay in the job.

\subsection{Objectives of the Study:}

$>$ To identify the physical problems faced by women employees in Information Technology industry.

$>$ To identify the psychological problems faced by women employees in Information Technology industry.

$>$ To find out the major reasons cited for quitting the job by women employees in Information Technology industry.

\section{REVIEW OF LITERATURE}

Gallivant (2002) and Moore (2002) found that women reported higher levels of stress and work exhaustion, relative to men in IT sector.

TABLE-1 PHYSICAL PROBLEMS

\begin{tabular}{|c|c|c|c|}
\hline S.No & Description & $\begin{array}{c}\text { No of } \\
\text { respondents }\end{array}$ & \%age \\
\hline 1 & $\begin{array}{l}\text { Backaches } \\
\text { a)Yes } \\
\text { b)No } \\
\text { Total }\end{array}$ & $\begin{array}{c}67 \\
53 \\
\mathbf{1 2 0}\end{array}$ & $\begin{array}{c}56 \\
44 \\
\mathbf{1 0 0}\end{array}$ \\
\hline 2 & $\begin{array}{l}\text { Frequent } \\
\text { Cold \& } \\
\text { Headache } \\
\text { a)Yes } \\
\text { b)No } \\
\text { Total }\end{array}$ & $\begin{array}{c}37 \\
83 \\
\mathbf{1 2 0} \\
\end{array}$ & $\begin{array}{c}31 \\
69 \\
\mathbf{1 0 0} \\
\end{array}$ \\
\hline 3 & $\begin{array}{l}\text { Continual } \\
\text { Tiredness } \\
\text { a)Yes } \\
\text { b)No } \\
\text { Total }\end{array}$ & $\begin{array}{c}66 \\
54 \\
\mathbf{1 2 0} \\
\end{array}$ & $\begin{array}{c}55 \\
45 \\
\mathbf{1 0 0} \\
\end{array}$ \\
\hline 4 & $\begin{array}{l}\text { Throat } \\
\text { Infection } \\
\text { a)Yes } \\
\text { b)No } \\
\text { Total } \\
\end{array}$ & $\begin{array}{c}39 \\
81 \\
\mathbf{1 2 0} \\
\end{array}$ & $\begin{array}{c}33 \\
67 \\
\mathbf{1 0 0} \\
\end{array}$ \\
\hline 5 & $\begin{array}{l}\text { Digestive } \\
\text { Disorder } \\
\text { a)Yes } \\
\text { b)No } \\
\text { Total } \\
\end{array}$ & $\begin{array}{c}60 \\
60 \\
\mathbf{1 2 0}\end{array}$ & $\begin{array}{c}50 \\
50 \\
\mathbf{1 0 0} \\
\end{array}$ \\
\hline
\end{tabular}

\begin{tabular}{|c|c|c|c|}
\hline 6 & $\begin{array}{l}\text { High Blood } \\
\text { Pressure } \\
\text { a)Yes } \\
\text { b)No } \\
\text { Total } \\
\end{array}$ & $\begin{array}{c}72 \\
48 \\
\mathbf{1 2 0} \\
\end{array}$ & $\begin{array}{c}60 \\
40 \\
\mathbf{1 0 0} \\
\end{array}$ \\
\hline 7 & $\begin{array}{l}\text { Feeling } \\
\text { Angry \& } \\
\text { Irritable } \\
\text { a)Yes } \\
\text { b)No } \\
\text { Total }\end{array}$ & $\begin{array}{c}75 \\
45 \\
\mathbf{1 2 0}\end{array}$ & $\begin{array}{c}63 \\
37 \\
\mathbf{1 0 0}\end{array}$ \\
\hline 8 & $\begin{array}{l}\text { Eye } \\
\text { Problem } \\
\text { a)Yes } \\
\text { b)No } \\
\text { Total }\end{array}$ & $\begin{array}{c}72 \\
48 \\
\mathbf{1 2 0}\end{array}$ & $\begin{array}{c}60 \\
40 \\
\mathbf{1 0 0}\end{array}$ \\
\hline 9 & $\begin{array}{l}\text { Respiratory } \\
\text { Illness } \\
\text { a)Yes } \\
\text { b)No } \\
\text { Total } \\
\end{array}$ & $\begin{array}{c}54 \\
66 \\
\mathbf{1 2 0} \\
\end{array}$ & $\begin{array}{c}45 \\
55 \\
\mathbf{1 0 0} \\
\end{array}$ \\
\hline 10 & $\begin{array}{l}\text { Sprains \& } \\
\text { Strains } \\
\text { a)Yes } \\
\text { b)No } \\
\text { Total }\end{array}$ & $\begin{array}{c}52 \\
68 \\
\mathbf{1 2 0}\end{array}$ & $\begin{array}{c}43 \\
57 \\
\mathbf{1 0 0}\end{array}$ \\
\hline
\end{tabular}

Halford V, Cohen HH (2003) concluded that the importance of psychosocial and organizational factors and employee welfare in the women call center-working environment. Musculo-skeletal disorders, ocular disorders and psycho-social problems were some of the key health problems observed among women IT professionals. There is a need for implementation of the programs that include the concepts of ergonomics, health education, training of personnel to prevent and overcome the morbidity, as well as psycho-social problems among women workers in ITES.

Parekh et al (2006) found that the symptoms increased with duration of span of computer use and with use of improper furniture. The symptoms were also more in spectacle-wearers, compared to non-spectacle users. The visual strain is also related to musculo-skeletal complaints and work stress. 


\section{RESEARCH METHODOLOGY}

Descriptive Research has been adopted for the present study. The information is obtained from primary as well as secondary sources. The primary data is in the questionnaire form and it is collected from the women employees at Information Technology industry in Coimbatore city. The sources for secondary data include books, journals and websites. Area of the study is confined to the Coimbatore city. Samples are collected from 120 women employees in Information Technology industry. Convenient sampling method is adopted for collecting primary data.

\subsection{Tools Used For Analysis: \\ $>$ Simple percentage analysis \\ $>$ Chi- square test \\ $>$ Correlation}

\subsection{Limitations of the Study}

This study is limited to find the problems faced by women employees working in Information Technology industry and the results are not generalized to other industries.

\section{RESULTS AND DISCUSSION}

The table- 1 shows the results related to physical problems faced by the women employees in Information Technology industry, 56\% of the respondents experience backache, $31 \%$ experiences frequent cold \& headache, continual tiredness is common among 55\%, 33\% are suffering from throat infection, $50 \%$ talk about minor and major digestive disorder, a major chunk is suffering from high blood pressure i.e. $60 \%$, $63 \%$ of the respondents complaint about feel angry $\&$ irritable, $60 \%$ experiences eye problem, $45 \%$ are diagnosed for respiratory illness and sprains \& strains are experienced by $43 \%$. Although these findings are consistent with already conducted studies, however from this study if was found that people unanimously felt that they should be given mandatory in-house medical check- ups for all employees.

The table- 2 depicts the psychological problems faced by the women employees. Some of the psychological problems identified in the study coincide with the previous studies conducted by Kumuda Tripathy (2005) who identified issues such as loss of identity, drug abuse and health related problems such as eye problems due to long hours of work, permanent night shifts, and high work targets), in this study also it was identified that most of the psychological problems are due to long hours of work, incredibly high work targets, loss of identity, inconvenience of shifts, increased stress, and lack of career prospects.

TABLE-2 PSYCHOLOGICAL PROBLEMS

\begin{tabular}{|c|c|c|c|}
\hline S.No & Description & $\begin{array}{c}\text { No of } \\
\text { respondents }\end{array}$ & $\%$ age \\
\hline 1 & $\begin{array}{l}\text { Anxiety } \\
\text { a)Yes } \\
\text { b)No } \\
\text { Total }\end{array}$ & $\begin{array}{c}66 \\
54 \\
\mathbf{1 2 0} \\
\end{array}$ & $\begin{array}{c}55 \\
45 \\
100\end{array}$ \\
\hline 2 & $\begin{array}{c}\text { Depression } \\
\text { a)Yes } \\
\text { b)No } \\
\text { Total }\end{array}$ & $\begin{array}{c}67 \\
53 \\
\mathbf{1 2 0}\end{array}$ & $\begin{array}{c}56 \\
44 \\
\mathbf{1 0 0}\end{array}$ \\
\hline 3 & $\begin{array}{c}\text { Faulty } \\
\text { Eating } \\
\text { Habits } \\
\text { a)Yes } \\
\text { b)No } \\
\text { Total }\end{array}$ & $\begin{array}{c}54 \\
66 \\
\mathbf{1 2 0}\end{array}$ & $\begin{array}{c}45 \\
55 \\
\mathbf{1 0 0}\end{array}$ \\
\hline 4 & $\begin{array}{c}\text { Mental } \\
\text { Tension } \\
\text { a)Yes } \\
\text { b)No } \\
\text { Total }\end{array}$ & $\begin{array}{c}71 \\
49 \\
\mathbf{1 2 0}\end{array}$ & $\begin{array}{c}59 \\
41 \\
\mathbf{1 0 0}\end{array}$ \\
\hline 5 & $\begin{array}{l}\text { Mental } \\
\text { Illness } \\
\text { a)Yes } \\
\text { b)No } \\
\text { Total } \\
\end{array}$ & $\begin{array}{c}47 \\
73 \\
\mathbf{1 2 0} \\
\end{array}$ & $\begin{array}{c}39 \\
61 \\
\mathbf{1 0 0} \\
\end{array}$ \\
\hline 6 & $\begin{array}{c}\text { Sleep } \\
\text { Disturbance } \\
\text { a)Yes } \\
\text { b)No } \\
\text { Total }\end{array}$ & $\begin{array}{c}66 \\
54 \\
\mathbf{1 2 0}\end{array}$ & $\begin{array}{c}55 \\
45 \\
\mathbf{1 0 0}\end{array}$ \\
\hline 7 & $\begin{array}{c}\text { Nightmares } \\
\text { a)Yes } \\
\text { b)No } \\
\text { Total }\end{array}$ & $\begin{array}{c}39 \\
81 \\
\mathbf{1 2 0} \\
\end{array}$ & $\begin{array}{c}33 \\
67 \\
100 \\
\end{array}$ \\
\hline
\end{tabular}

It is identified from table-3 that a little less than half of the respondents (45\%) want to quit their job for increased stress. Stress is the major issue 
that makes the women employees in the Information Technology sector to quit their job. Stress reactions may result when people are exposed to risk factors at work. These reactions are emotional, cognitive, behavioural and/or physiological in nature. When stress reactions persist over a longer period of time, they develop into more permanent, less reversible health outcomes, such as chronic fatigue, burnout, musculoskeletal problems or cardiovascular disease Hoogendoorn et al, (2000).

TABLE-3: Reasons for Quitting the Job by Employees

\begin{tabular}{|c|c|c|c|}
\hline S.No & Description & $\begin{array}{c}\text { No of } \\
\text { respondents }\end{array}$ & \%age \\
\hline 1 & $\begin{array}{c}\text { Inconvenience } \\
\text { of shifts }\end{array}$ & 21 & 17 \\
\hline 2 & $\begin{array}{c}\text { Increased } \\
\text { stress }\end{array}$ & 54 & 45 \\
\hline 3 & $\begin{array}{c}\text { Lack of career } \\
\text { prospects }\end{array}$ & 45 & 38 \\
\hline & Total & 120 & 100 \\
\hline
\end{tabular}

The table-4 shows that there is a significant relationship between marital status and feeling angry $\&$ irritable. The married women employees feel angry \& irritable which is less among the unmarried. When the worker perceives an imbalance between demands and environmental or personal resources, this can cause a number of possible reactions. This include emotional responses (e.g. feeling nervous or irritated), when people are in a state of stress, they often feel concerned, less vigilant and less efficient in performing tasks (Barling et al, 2004).

TABLE-4: Relationship between Marital Status and Feeling Angry \& Irritable

\begin{tabular}{|l|l|l|l|}
\hline $\begin{array}{l}\text { Marital } \\
\text { status }\end{array}$ & Yes & No & Total \\
\hline Married & 30 & 18 & 48 \\
\hline Unmarried & 45 & 27 & 72 \\
\hline Total & 75 & 45 & 120 \\
\hline
\end{tabular}

Null hypothesis H0: There is no significant relationship between marital status and feeling angry \& irritable.

Alternative hypothesis H1: There is significant relationship between marital status and feeling angry \& irritable.

The table-5 interprets that there is a positive correlation between health affected by work and reason to quit the job. Therefore employees quit their job if their health is been affected.

TABLE-5: Relationship between Health Affected By Work and Reason to Quit the Job

\begin{tabular}{|c|c|c|c|c|c|c|c|}
\hline S.No & $\mathbf{X}$ & $\mathbf{Y}$ & $\mathbf{X}=\mathbf{X}-\overline{\boldsymbol{X}}$ & $\mathbf{y}=\mathbf{Y}-\overline{\boldsymbol{Y}}$ & $\mathbf{X}^{\mathbf{2}}$ & $\mathbf{Y}^{\mathbf{2}}$ & $\mathbf{X Y}$ \\
\hline 1 & 33 & 21 & -7 & -19 & 49 & 361 & 133 \\
\hline 2 & 68 & 54 & 28 & 14 & 784 & 196 & 392 \\
\hline 3 & 19 & 45 & 21 & 5 & 441 & 25 & 105 \\
\hline Total & $\sum \mathrm{X}=120$ & $\sum \mathrm{Y}=$ & $\sum \mathrm{x}=0$ & $\sum \mathrm{y}=0$ & $\begin{array}{c}\sum \mathrm{x}^{2}= \\
1274\end{array}$ & $\begin{array}{c}\sum \mathrm{y}^{2}= \\
582\end{array}$ & $\begin{array}{c}\sum \mathrm{xy}= \\
630\end{array}$ \\
\hline
\end{tabular}

\section{SUGGESTIONS}

Companies have to understand the requirement of managing stress among women to make the environment conducive which can retain skilled talented women. Management must provide continuous learning, mentoring, coaching, counseling, opportunities for self development, time management to handle their responsibility at home along with office to encourage them to take higher responsibilities of onsite projects. Women employees should upgrade their skills with technological advancement which would help them to overcome the mental harassment at their work place.

\section{CONCLUSION}

Thus it can be concluded that in information technology industry, the participation of women employees is affected by socio constraints, night- 
shift, long- working hours and highly challengeable nature of jobs. The research wok identified various physical and psychological problems faced by women employees in Information Technology industry. The suggestions have been provided if followed may help the women employees and also Information Technology industry to overcome their problems.

\section{REFERENCES}

[1] Ahuja MK(2002), “ Women in IT profession: A literature review, syntheses, and Research Agenda", European Journal of Information Systerm, vol.11, pp. 20-34.

[2] Barling, J. et al (ed.), The Handbook of Work Stress, Sage, California, 2004.

[3] Chew. S.B. and R. Chew (1990), 'Information Technology as a Strategy Human Resource Development for women', in E.C.Y. Kuo, C.M. Loh and K.S. Raman, Information Technology in Singapore Society: Trends, Policies and Applications, Singapore University Press.

[4] Gallivant MJ (2002), "The Influence of software Developers' creative style on their attitude to and assimilation of a software process innovation", Journal of Information Technology and Management, vol. 19, pp. 141-165

[5] Halford V, Cohen HH. Technology use and psychosocial factors in the self reporting of musculo skeletal disorder symptoms in women call center workers. J Safe Res 2003; 34:2:167-73.

[6] Hoogendoorn(2000), W.E., Poppel, M.N.M. van, Koes, B.W. and Bouter,

L.M., 'Systematic review of psychosocial factors at work and private life as risk factors for back pain', Spine, 25, 2000, pp. 2114-2125.

[7] Kumuda Tripathy (2005),"Labour in Business Process Outsourcing: A Study on the worklife of women BPO employees and the various problems faced by them while working in the BPO sector", NLI Research Studies Series No.51, V.V.Giri National Labour Institute, Noida,

[8] Parekh KJ, Singh AK, Sarkar P, Sharma RP(2006), editors. Symptoms in women computer users and ergonomics solutions. Proceedings of 56th National conference on occupational health, safety and environment. IAOH: Jamshedpur, India;

[9] http://en.wikipedia.org/wiki/women employees in it sector- problems

[10] http://www.nbrill.com/it it sector women employees' problem- it sector.

[11] http://www.nbrill.com/it /about information technology sector

[12] http://www.india-articles.com/healthcare/skin-care/employed-in-a-bpo.html

[13] http://scienceray.com/technology/introd uction-to-the-information-technologysector/\#ixzz1HzrBkqLI

[14] http://www.un.org/womenwatch/daw/fol lowup/session/presskit/fs3.html 